\title{
Assessment the Content of Methanil Yellow and Boraks at Traded Food Market in Makassar
}

\author{
Alfina Baharuddin 1 , Suharni A. Fachrin ${ }^{2}$, Nurbaety ${ }^{3}$, Salma $^{4}$ \\ ${ }^{1}$ Lecturer of Environmental of Public Health, University Moslem of Indonesia, ${ }^{2}$ Lecturer of Occupational of \\ Publich Health, University Moslem of Indonesia, ${ }^{3}$ Lecturer Publich Health, University Moslem of Indonesia, \\ ${ }^{4}$ Postgraduated Faculty of Publich Health, University Moslem of Indonesia
}

\begin{abstract}
The market is one of the public places frequented by the public, thus allowing transmission of the disease both directly and indirectly through vectors such as flies. Market cleanliness must be kept clean so that food contamination is less likely to occur so that the food to be consumed remains good, clean and safe to eat. This reseach to identification boraks and methanil yellow. The sample is a portion taken from the whole object under study and is considered to represent the population. Sampling in this study was conducted by total sampling for interviews with hawker food vendors. food samples to see the content of Borax and 3 food and beverage samples to see the content of Rodamint B. The content of Borax and Rhodamin in street food vendors in the Eggplant Market shows that 6 traders who tested the content of Borax on meatballs obtained negative results, while for 3 traders tested the content of Rhodamin B in food sold obtained positive results or did not meet the requirements for consumption. Hygiene in serving food obtained that $20(64.5 \%)$ hawker food vendors in the Eggplant Market did not meet the requirements. Hygiene and sanitation of sales locations shows that $20(64.5 \%)$ of traders are in sales locations that are not good or have not met the requirements.
\end{abstract}

Keywords: Boraks, methanil Yellow, Personal hygine.

\section{Introduction}

Food snacks as one of the community services in the field of food, which is often still far from meeting health requirements that cause disease to the community ${ }^{1}$. By seeing the potential for such large food and high levels of vulnerability, efforts to monitor the quality of snacks are managed by taking into account hygiene and sanitation rules and health requirements. About $80 \%$ of food-borne diseases are caused by pathogenic bacteria. Some types of bacteria that often cause disease include: Salmonella, Staphylocokkus, Escherichia coli, Vibrio, Clostridium, Shigella and Psedomonas Cocovenenous ${ }^{1,2,3}$.

Food outlets and food handlers available in public places should receive special attention from the

\footnotetext{
Coressponding Author:

Alfina Baharuddin

Lecturer of Environmental of Public Health, University

Moslem of Indonesia

e-mail: alfina.baharuddin@umi.ac.id
}

government in order to present good and safe snacks for consumption. One of the public places where there are traders who provide various snacks is traditional markets such as the Makassar Terong Market Snacks sold in markets are needed considering the activity in the market occurs from morning and even usually happens in the afternoon. Snack food that is often sold in the market is cheap enough so that it is in demand by many people. Noteworthy is not only snacks at low prices but we also need to consider the cleanliness of these foods. Of course we want snacks that are cheap, tasty, also have good nutrition and hygiene and can support the health of the human body $4,5,6$.

Snack food is very risky for health such as infection by microorganisms, pathogens, poisoning, cancer risk and others that are not yet known by researchers. This risk can occur because of the lack of knowledge about the safety of snacks. These risks can be minimized if in the presentation, as well as at the time of distribution or sale are considered things that can cause health risks. Noteworthy is not only snacks at low prices but we 
also need to consider the cleanliness of these foods ${ }^{7,8,9}$. Of course we want snacks that are cheap, tasty, also have good nutrition and hygiene and can support the health of the human body. Snack food is very risky for health such as infection by microorganisms, pathogens, poisoning, cancer risk and others that are not yet known by researchers. This risk can occur because of the lack of knowledge about the safety of snacks. These risks can be minimized if in the presentation, as well as at the time of distribution or sale are considered things that can cause health risks ${ }^{10,11,12}$.

There are quite a number of hawker food vendors in the Eggplant Market considering that the Eggplant Market is a fairly large traditional market and the activity of traders in the market sometimes takes place from morning to evening, it is possible that snacks sold can be contaminated with pollutants, bacteria or germs that can disturb health when consumed by humans ${ }^{13,14}$. In addition, there are some hawker food traders who trade in places that are not good food at Pasar Terong quite a lot considering that Pasar Terong is a fairly large traditional market and the activities of traders in the market sometimes take place from morning to evening, do not rule out food snacks that are sold can be contaminated with pollutants, bacteria or germs that can interfere with health if consumed by humans. In addition, there are some hawker food traders who trade in places that are not good.

\section{Method}

The population is Snack food is very risky for health such as infection by microorganisms, pathogens, poisoning, cancer risk and others that are not yet known by researchers. This risk can occur because of the lack of knowledge about the safety of snacks. These risks can be minimized if in the presentation, as well as at the time of distribution or sale are considered things that can cause health risks.

\section{Result}

Table 1: Distribution of Respondents Based on Hygiene and Sanitation Food Handler in Pasar Terong Bontoala District

\begin{tabular}{|c|c|c|c|c|c|c|}
\hline \multirow{2}{*}{ Food Handlers Hygiene } & \multicolumn{2}{|c|}{ Yes } & \multicolumn{2}{|c|}{ No } & \multicolumn{2}{|c|}{ Total } \\
\hline & $\mathbf{N}$ & $\%$ & $\mathbf{N}$ & $\%$ & $\mathbf{n}$ & $\%$ \\
\hline Use of food tongs & 12 & 38,7 & 19 & 61,3 & 31 & 100 \\
\hline The use of plastic gloves & 3 & 9,7 & 28 & 90,3 & 31 & 100 \\
\hline Maintain cleanliness of nail & 31 & 100 & 0 & 0 & 31 & 100 \\
\hline Use of aprons & 12 & 38,7 & 19 & 61,3 & 31 & 100 \\
\hline Wash hands before serving & 2 & 6,5 & 29 & 93,5 & 31 & 100 \\
\hline Speak when serving & 30 & 96,8 & 1 & 3,2 & 31 & 100 \\
\hline Use jewelry/accessories & 15 & 48,4 & 16 & 51,6 & 31 & 100 \\
\hline
\end{tabular}

Table 2: Distribution of Respondents Based on Borax Content in Meatballs in Pasar Terong Bontoala District

\begin{tabular}{|c|c|c|}
\hline Code Sample & The Contant of Boraks & Information \\
\hline B 1 & Negatif & Eligible \\
B 2 & Eligible \\
B 3 & Negatif & Eligible \\
B 4 & Negatif & Eligible \\
B 5 & Negatif & Eligible \\
B 6 & Negatif & Eligible \\
\hline
\end{tabular}


Based on Table 2 shows that the results of laboratory tests on the content of Borax on meatballs sold in the eggplant market are negative and do not contain Borax. Based on the results of laboratory tests obtained the results that the meatballs used as samples are free from borax content so that it is safe for consumption by the buyer (consumer).

Table 3: Rhodamin B content in cakes and ice in Pasar Terong Bontoala District Makassar

\begin{tabular}{|c|c|c|}
\hline Code sample & Information & Keterangan \\
\hline Es " $\mathrm{X}$ " & Positif & Not eligible \\
$\mathrm{K} 1$ & Positif & Not eligible \\
$\mathrm{K} 2$ & Positif & Not eligible \\
\hline
\end{tabular}

Table 4: Shows that the results of laboratory tests on Rhodamin $B$ content in cakes and ice sold Positive (+) containing Rodamin B Dyes

\begin{tabular}{|l|c|c|}
\hline Chemical Test & N & \% \\
\hline Not inspected & 23 & 71,8 \\
Not eligible & 3 & 9,4 \\
Eligible & 6 & 18,8 \\
\hline Total & $\mathbf{3 2}$ & $\mathbf{1 0 0}$ \\
\hline
\end{tabular}

\section{Discussion}

Snack food ingredients are materials used in processing snacks. In terms of quality, in addition to containing all the substances needed by the body food must also meet safety requirements. Based on the results of research conducted on 31 respondents in the Terong Market Bontoala District of Makassar City, the results obtained are that most traders use natural ingredients/ materials in accordance with the requirements of the Minister of Health Decree No. 942 of 2003. Laboratory test results regarding the content of borax in meatballs traders in the Terong Market, Bontoala District, Makassar, showed that 6 traders whose meat samples were taken as samples and had been examined in the laboratory showed negative results or no borax content in the meatballs.

The results of this study are not in line with research on the identification of snacks containing borax in traders in Semarang City markets. From the research results, it was found that there are 3 types of snacks that positively contain Borax, namely: gendar (100\%) positively containing Borax, lopis $(50 \%)$ containing Borax, and cenil (25\%) containing Borax. Other types of snacks, namely: rice cake, sentiling, and putu mayang do not contain Borax. From the overall snacks sample studied, 29\% contained Borax.

Laboratory test results regarding the content of Rhodamin B in 2 cake traders and one ice trader in the Terong Market in the Bontoala District of Makassar were obtained that all traders whose food samples were taken and examined in the laboratory showed positive results or contained Rhodamin B. The results of this study are in line with research conducted on the identification of snack foods containing Forbidden Dyes at traders in Semarang City Markets. From the results of the study it was found that $50 \%$ of the food samples studied contained dyes that could not be used in snacks, snacks containing prohibited dyes, namely: cenil, centiling, and putu mayang.

Rhodamin B synthetic dyes are found in food products that should be used for textile dyes. Although it has a low toxicity, consumption of large amounts or repeatedly causes cumulative properties of respiratory tract irritation, skin irritation, eye irritation, irritation of the digestive tract, poisoning, and liver disorders. From these results it was found that $24(77.4 \%)$ traders were not tested for their food ingredients, because the tested foods were suspected of containing Borax and Rhodamin B. For testing Borax was taken from 6 meatball traders, while for Rhodamin B was taken from food are red and are thought to contain Rhodamin B. Based on the results of field observations made at the Terong Market in Bontoala District, Makassar City by researchers regarding hygiene in serving snacks, it was found that the majority of traders who served their food openly were $20(64.5 \%)$, this meant that hygiene in serving snacks was served not eligible ${ }^{15}$.

The Terong Market area is located in the middle of the city, where vehicles often pass by which can cause pollution or contamination of snacks sold by traders.Food outlets and food handlers available in public places should receive special attention from the government so that merchants serve good, safe food for consumption. Food contamination can occur due to poor sales locations, close to pollution sources such as high frequency traffic Based on the results of research that has been done for the variable location of sales obtained that most of the traders maintain the cleanliness of their sales location, while traders who have a sales location are close to polluting sources as many as 20 (64.5\%). This data is based on the results of direct observations and interviews, the location of the sales of hawker food 
vendors in Pasar Terong partly located beside the roads that are often traversed by vehicles, those that trade beside used clothing sellers (claws), and are right in front of the garbage dump

The data illustrates that hygiene and sanitation of merchant sales locations in Terong Market, Bontoala District, Makassar City, the majority (64.5\%) are not good or have not met the requirements for good, clean and safe street food sales. The results of this study are in line with the results of research conducted by Pratiwi (2012) on traders in the traditional market area of Kaliyoso Village. From the results of the study obtained a description that all traders (100\%) in the Kaliyoso Traditional Market. Food hygiene sanitation in terms of sales location does not meet the requirements.

\section{Conclution}

1. The content of Borax and Rhodamin in street food traders that 6 traders tested the content of Borax on meatballs obtained negative results, while for 3 traders tested the content of Rhodamin B in food sold obtained positive results or did not meet the requirements for consumption .

2. Hygiene in serving food obtained that $20(64.5 \%)$ hawker food vendors in the Eggplant Market did not meet the requirements.

3. Hygiene and sanitation of sales locations shows that $20(64.5 \%)$ of traders are in sales locations that are not good or have not met the requirements.

Source of Funding: Self-funding

Conflict of Interest: None of the authors has competing interests.

Ethical Clearance: taken from Comitee ethical Clearence Universitas Muslim of Indonesia Makassar

\section{References}

1. Trestiati, M. Analisis Rhodamin B pada Makanan dan Minuman Jajanan Anak SD (Studi Kasus : Sekolah Dasar di Kecamatan Margaasih Kabupaten Bandung). ITB. 2003

2. Widyaningsih, T.D., dan Murtini, E. S. Alternatif Pengganti Formalin pada Produk Pangan, Identifikasi Formalin Pada Bakso Dari Pedagang Bakso Di Kecamatan Panakukkang. Makassar. 2006.

3. Wijaya, D. (2011). Waspadai Zat Aditif dalam Makananmu. Jogjakarta: Bukubiru.
4. Alsuhendra, \& Ridawati. (2013). Bahan toksik dalam makanan. Jakarta: Rosda.

5. Cahyadi, W., dan Sukayada, I. M. Analisis dan Aspek Kesehatan Bahan Tambahan Pangan. Jakarta: Bumi Aksara. 2008.

6. Hastuti, S.Analisis kualitatif dan Kuantitatif Formaldehid Pada Ikan Asin di Madura. Jurnal Agrointek, 4(2), 132-137. 2010

7. Jana, J. Studi Penggunaan Pewarna Sintetis (Sunset Yellow, Tartrazine dan Rhodamin B) Pada Beberapa Produk Pangan di Kabupaten Sukabumi. Sukabumi. 2007

8. Mahdi, C. Mengenal Berbagai Produk Reagen Kit Tester Untuk Uji Formalin, Borak, Zat pewarna Berbahaya dan Kandungan Yodium Pada Garam Beryodium. Malang: Universitas Brawijaya Malang. 2008.

9. Nollet. Analisa Rhodamin B dan Metanil Yellow dalam Minuman Jajanan Anak SD di Kecamatan Laweyan Kotamadya Surakarta Metode Kromatografi Lapis Tipis. Universitas Muhamadiyah SurakartaDepkes RI. Peraturan Mentri Kesehatan Repulik Indonesia No.722/ Menkes/IX/1988. Tentang Badan Tambahan Makanan, Pub. L. No. No.722/Menkes/IX/1988 (1988). Indonesia.2008.

10. Djalil, A.D., Hartanti, D., Rahayu, W.S., Prihatin, R., Hidayah, N. Identfikasi Zat Warna Kuning Metanil (Metanil Yellow) dengan Metode Kromatografi Lapis Tipis (KLT) pada Berbagai Komposisi Larutan Pengembang. Jurnal Farmasi. 2005

11. Djamhuri, A. Racun dalam Makanan. Surabaya: Airlangga University Press.2009

12. Donatus, I. A. Toksikologi Pangan, PAU Pangan dan Gizi. Yogyakarta: UGM,1990.

13. Faradila, Elmatris, dan Yustini, A. Identifikasi Formalin pada Bakso yang Dijual pada Beberapa Tempat di Kota Padang. Jurnal Kesehatan Andalas, 3(2), 156-158. 2013.

14. Rosyidah, A., Purwanti E., Hartanto D., Murwani IK., Prasetyoko D., dan E. R. Penataan Pkl Bebas Boraks Dan Formalin Menuju Produk Unggulan Sehat Dan Higienis. Qardhul Hasan: Media Pengabdian Kepada Masyarakat, 3(2), 86-98.

15. Saptarini, N, Wardati, Y., dan Supriatna, U. Deteksi Formalin dalam Tahu di Pasar Tradisional Purwakarta. Bandung: Universitas Padjadjaran. 2011 